\section{Spinalenheter og andre enheter}

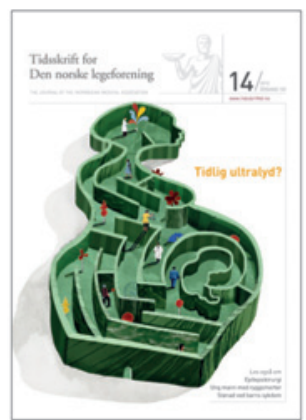

I Tidsskriftet nr. 14/2012 om temaserien om ryggmargsskader problematiserer Ragnar Stien to felter (1): begrepet «spinalenhet» på den ene siden og viktigheten av tette bånd mellom akuttbehandling og rehabilitering og oppfølging av ryggmargsskader på den andre.

Det er viktig at akuttbehandlere har kunnskap om langtidsutfall som grunnlag for evaluering av sin virksomhet i tillegg til at det bør være tett kontakt og felles vurderinger når det gjelder eventuell

kirurgisk behandling av komplikasjoner. Stien har nok et poeng i at samarbeid mellom akutt- og rehabiliteringsmiljøene kan forbedres, selv om mitt inntrykk er at dette står i sentrum hos de ryggmargsskadebehandlende og -rehabiliterende miljøene i Norge. Et tettere samarbeid er nok ikke minst også mulig mellom miljøene som gjennomfører kirurgisk behandling av ryggmargsskadede.

Når det gjelder begrepsbruken, synes Stien å forutsette at begrepet «enhet» kun kan brukes hvis behandlingen på en enhet omfatter alt fra akuttbehandling til langtidsoppfølging. Jeg tror få avdelinger i norsk helsevesen er organisert slik. Et eksempel er slagenhetene som står for akuttbehandling og tidlig rehabilitering av slagpasienter de første par ukene etter slaget, men som regel ikke videre oppfølging, unntatt eventuelt en poliklinisk kontroll 3-6 måneder etter slaget (som heller ikke alltid er tett knyttet opp mot slagenheten). Mye av den videre behandlingen og oppfølgingen innenfor spesialisthelsetjenesten, spesielt den delen som er rettet mot funksjonsnedsettelsene på grunn av hjerneslaget, skjer i rehabiliteringsavdelinger. Selv om dagens slagenheter dermed ikke er «comprehensive» i den forstand Stien nevner, synes «slagenhet» å være et nyttig begrep.

\section{Frank Becker}

frank.becker@medisin.uio.no

Frank Becker (f. 1969) er spesialist i fysikalsk medisin og rehabilitering. Han er seksjonsoverlege ved Seksjon for hjerneskader ved Sunnaas sykehus og førsteamanuensis ved Institutt for klinisk medisin, Universitetet i Oslo.

Ingen oppgitte interessekonflikter

\author{
Litteratur \\ 1. Stien R. Tema: Ryggmargsskader. Tidsskr Nor Legeforen 2012; 132: 1584
}

Publisert som rask respons i nettutgaven 16.8. 2012

\section{Bivirkninger av bisfosfonater}

Erik Fink Eriksen \& Johan Halse diskuterer i Tidsskriftet nr. 14/2012 indikasjoner for seponering av bisfosfonater (1). Jeg har selv ingen kompetanse innen osteoporosebehandling og har ikke innvendinger mot konklusjonene i kronikken, men vil kommentere det jeg oppfatter som en bagatellisering av kjeveosteonekrose som bivirkning. Bisfosfonatrelatert kjevebeinsosteonekrose ( bisphosphonate-related osteonecrosis of the jaws, BRONJ) er en alvorlig bivirkning som definisjonsmessig innebærer blottlagt nekrotisk kjevebein. Alvorlige infeksjoner og sekvestrering oppstår ofte sekundært. Slik nekrose utløses gjerne av et traume, et typisk eksempel er tanntrekking, men kan også oppstå spontant. Selv om kronikkforfatterne påpeker at «en direkte patogenetisk sammenheng med bisfosfonatbruk mangler», kan det ikke være tvil om en klar årsakssammenheng $(2,3)$. At man derimot «har kartlagt en rekke andre risikofaktorer som disponerer for kjevebeinsosteonekrose» er ukjent for meg.

Det finnes i dag ingen etablerte kurative behandlingsregimer mot bisfosfonatrelatert kjevebeinsosteonekrose. Risikoen er utvilsomt høyest for intravenøst administrerte bisfosfonater gitt på onkologisk indikasjon, der kumulativ insidens i enkelte studier er blitt angitt til over $10 \%$ (2). Ved osteoporosebehandling med perorale bisfosfonater er nekrose, som Eriksen \& Halse påpeker, et mindre problem i forhold til nytteverdien. Det er imidlertid tegn som tyder på at slik nekrose også i denne pasientgruppen forekommer hyppigere enn tidligere antatt, med kumulativ insidens på opp mot $1 \%$ etter tannekstraksjoner (2). Dette kan synes lite, men flere titusener behandles med bisfosfonater på osteoporoseindikasjon i Norge. Tatt i betraktning alvorlighetsgraden og fravær av effektive behandlingsregimer er dette derfor et stort problem for et økende antall pasienter (4). Underrapportering er antakelig utbredt: Ved en gjennomgang av de siste 25 registrerte BRONJ-tilfellene ved egen avdeling var kun ett meldt til Relis. Samtaler med andre kjevekirurgiske avdelinger bekrefter at tilsvarende underrapportering dessverre er vanlig. For øvrig var 15 av tilfellene oppstått etter peroral bisfosfonatmedikasjon på osteoporoseindikasjon. Kun en av disse har siden blitt friskmeldt for denne typen nekrose.

Jeg er enig med Eriksen \& Halse i at risiko for eller etablert bisfosfonatrelatert kjevebeinsosteonekrose ikke nødvendigvis er indikasjon for seponering av bisfosfonater. Behandlere av osteoporose må allikevel være klar over problemstillingen, og det bør etter min mening oppfordres til tannlegeundersøkelse for sanering av dårlige tenner og potensielle infeksjonsfoci før bisfosfonatbehandling iverksettes.

\section{Sigbjørn Løes}

sigbjorn.loes@odont.uib.no

Sigbjørn Løes (f. 1975) er dr. philos., førsteamanuensis og spesialist i oral kirurgi og oral medisin, Kjevekirurgisk avdeling. Haukeland universitetssykehus og Det medisinsk-odontologiske fakultet, Universitetet i Bergen.

Oppgitte interessekonflikter: Han er prosjektmedarbeider (ulønnet) i «DEMAB - Sikkerhetsstudie av nytt osteoporosemedikament» (denosumab), et multinasjonalt prosjekt finansiert av Amgen).

\section{Litteratur}

1. Eriksen EF, Halse J. Når seponere bisfosfonater? Tidsskr Nor Legeforen 2012; 132: $1630-2$

2. Yamazaki T, Yamori M, Ishizaki T et al. Increased incidence of osteonecrosis of the jaw after tooth extraction in patients treated with bisphosphonates: a cohort study. Int J Oral Maxillofac Surg 2012; e-publisert 26.7.2012. http://dx.doi.org/ 10.1016/j.ijom.2012.06.020

3. Marx RE. Uncovering the cause of «phossy jaw» Circa 1858 to 1906: oral and maxillofacial surgery closed case files-case closed. J Oral Maxillofac Surg 2008; 66: $2356-63$.

4. Løkken P, Skoglund LA, Skjelbred P. Kjeveosteonekrose ved bisfosfonatbehandling. Tidsskr Nor Lægeforen 2007; 127: 1945-7.

Publisert som rask respons i nettutgaven 15.8. 2012

\section{E.F. Eriksen \& J. Halse svarer:}

Vi takker for kommentaren til vår artikkel, men vi er uenige i flere av de fremsatte synpunktene. For det første må osteoporosepasienter og kreftpasienter behandles separat når det gjelder risiko. Kreftpasienter har mer enn 100 ganger høyere risiko for kjeveosteonekrose enn pasienter i behandling for benign sykdom (1). Derfor understrekes behov for tannlegeundersøkelse før start av bisfosfonatbehandling kun for kreftpasienter i preparatomtalene for bisfosfonater fra EMEA og FDA. Odontologisk undersøkelse av alle osteoporosepasienter før behandlingsstart virker overdrevet i betraktning av den lave risikoen for kjeveosteonekrose hos pasien- 